\author{
Oksana Lugovska and Vasyl Sydor
}

\title{
HYDROCOLLOIDS EFFECT ON THE QUALITY OF OIL-WATER EMULSION FOR FOODSTUFFS AND BEVERAGES
}

\author{
National University of Food Technology, \\ 68 Volodymyrska St., 01033 Kyiv, Ukraine; oksana.lugovska320@gmail.com
}

Received: February 27, 2015 / Revised: J uly 20, 2015 / Accepted: December 23, 2015

(c) Lugovska O., Sydor V., 2016

\begin{abstract}
The procedure of emulsion preparation with hydrocolloids which are stabilizer-emulsifiers, namely gum-arabic and starch, was updated by introducing new technological parameters, such as oil:aqueous phase ratio, sequence and parameters of ingredients introduction, parameters of pre-emulsion preparation and homogenization. The food emulsion samples were investigated using different amounts of gum-arabic and starch at constant amount of oil phase and samples with variable amount of oil phase and constant amount of a stabilizer. The optimum ratio between aqueous stabilizer and oil phase is characterized by maximum number of emulsion particles with the size under 1 micron.
\end{abstract}

Keywords: aromatic emulsion, hydrocolloid, stabilizer, starch, gum-arabic.

\section{Introduction}

Emulsions are widely used in many branches of food technology. While using aromatic emulsions in nonalcoholic beverages production a series of advantages is observed, in particular the blending time is decreased as there is no need to add aromatizer, to choose dye and stabilizer. The problem of aroma and flavor stability is also solved because in such a case an emulsifier plays a role of aromatic part adsorbent and provides delicate and mild aroma.

In the restaurant business and public catering the emulsions are used for flavoring and coloring the alcoholic beverages, which are prepared on the basis of alcohol, sugar, citric acid and addition of concentrated juices, depending on the recipe of the finished beverage.

The advanced technology of aromatic emulsions is associated with the peculiarities of hydrocolloids application. Constant attention to the research of these compounds is stipulated by their importance for the food industry. However, despite the large number of studies on the physical and chemical properties of hydrocolloids, there is insufficient scientifically based data on their use in food emulsions [1].

Therefore, it is actual and prospective to establish some regularities concerning the effect of main factors of emulsion production: choice of hydrocolloids, water and oil phases ratio, sequence of components introduction, time, temperature and mixing parameters. This will facilitate the development of new formulations and process optimization.

The theory of emulsification mechanism is described in the literature. The first stage is droplets extension in the area of dispersive medium. This process is accompanied by increased surface and energy to overcome the molecular forces of surface tension. The extended droplet becomes so unstable that it spontaneously breaks up into small spherical droplets. This is the second stage of emulsions formation, accompanied by increased surface. At the third stage the formed drops coagulate during collisions, on the one hand, and on the other hand - they are again extended into smaller ones to establish equilibrium. A spontaneous decay of drops extended to unsustainable sizes is a basis for increased dispersion of emulsions [2-4].

The stable emulsion obtaining is associated with the dispersion mechanism and depends on many factors, such as oil content, emulsifier type and concentration, a method of phase introduction, dispersion intensity and degree, temperature. The dispersion degree is the key factor for stable emulsions [5-9]. High rates of stirring [9] and high pressure in a homogenizer increase dispersion and viscosity and result in formation of more stable emulsions.

R. Whistler et al [7, 8] proved the optimum ratio between aqueous and oil phases for every type of 
emulsifier. The introduction of excessive oil results in emulsion aliquation.

The emulsion breakdown is described by destabilization rate, $V$, according to the Stokes' law:

$$
V=\frac{2 \cdot r^{2}\left(d_{1}-d_{2}\right) \cdot g}{9-q}
$$

where $V$ - destabilization rate of emulsion, $\mathrm{m} / \mathrm{s} ; d_{1}$ and $d_{2}$ - density of dispersed and dispersing phase, respectively, $\mathrm{kg} / \mathrm{m}^{3} ; q$ - medium viscosity, $\mathrm{Pa} \cdot \mathrm{s} ; r$ - radius of oil particle, $\mathrm{m} ; \mathrm{g}$-acceleration of gravity, $\mathrm{m} / \mathrm{s}^{2}$.

To decrease the destabilization rate it is necessary to use oil of high density (about $1.0 \mathrm{~g} / \mathrm{cm}^{3}$ ) or increase the density of light oils (e.g. citrus oil with $\left.d=0.8 \mathrm{~g} / \mathrm{cm}^{3}\right)$ by introducing compounds allowable to be used in foodstuffs, e.g. resingum.

To decrease the radius of oil particles to $0.4-1.0 \mu \mathrm{m}$ the stirring with high shift tension and emulsion homogenization under the pressure of 9.829.4 MPa are used. Under mentioned size of particles the coalescence is minimal and strong turbidity occurs which is an important characteristic of the finished emulsion.

Now the starch and gum-arabic are most widely used hydrocolloids or stabilizers-emulsifiers for emulsions production.

The modified starch-emulsifier (E1450) has emulsifying and foam-stabilizing properties due to etherification of starch by octenylsuccinic acid. Gum-arabic (E414) is a natural exudate obtained from acacia trees (acacia gum) growing in Africa. Acacia gum is characterized by strongly branched arabinogalactan structure with protein fraction in the centre which forms a low-viscous solution providing good emulsifying properties [10].

On the basis of literature data [10] concerning application of gum-arabic and starch for the emulsions production we studied them in order to improve their application. The disadvantage of known methods is impossibility of components complete dissolution. Moreover, the data about the ratio between oil and aqueous phases, temperature, time and rate of stirring, parameters of pre-emulsion preparation (rate of time of aqueous and oil phases stirring), and homogenization process (optimum pressure) are absent in the literature.

Thus, the aim of this work is to update the existing technology of emulsion preparation with gum-arabic and starch via introduction of new technological parameters to obtain stable emulsion with maximum number of particles up to $1 \mu \mathrm{m}$ and to prevent such disadvantages of food emulsions as creaming (breakdown of emulsion due to enlargement of oil particles and their flotation to the emulsion surface) and ringing (formation of oil ring on the beverage surface during its storage).

\section{Experimental}

\subsection{Starting Materials}

The emulsions based on citrus oil were used for the investigations. Gum-arabic (CNI, France) and modified starch (National Starch, Germany) were the stabilizers.

To study the emulsifying properties different types of emulsions were prepared. According to the specification [10] the emulsions contain gum-arabic of high purity (4-7 wt \%) and oil phase of 8-14 wt \%. The emulsions with starch contain 8-14 wt \% of E1450 and 8$14 \mathrm{wt} \%$ of oil phase. The emulsions contain different amount of oil phase and constant amount of stabilizer (Tables 1 and 3), as well as constant amount of oil phase with variable amount of stabilizer (Tables 2 and 4).

Resingum was added to equalize the difference between oil and water density; the density of essential oils is around $0.845 \mathrm{~g} / \mathrm{cm}^{3}$ and density of water is $1.0 \mathrm{~g} / \mathrm{cm}^{3}$.

To prevent oil oxidation in the emulsion we used antioxidant - antracine (blend of E320 and E321).

To prevent microbiological damage the sodium benzoate (E211) was used as a preservative in the amount of $0.17 \mathrm{wt} \%$ relative to the finished product.

Table 1

Emulsions with different amount of oil phase and constant amount of gum-arabic

\begin{tabular}{|c|c|c|c|c|c|}
\hline \multirow{3}{*}{ Emulsion ingredients } & \multicolumn{5}{|c|}{ Ingredients content, wt \% } \\
\hline & \multicolumn{5}{|c|}{ Emulsion number } \\
\hline & 1 & 2 & 3 & 4 & 5 \\
\hline Citrus oil & 6.000 & 6.000 & 6.000 & 6.000 & 7.000 \\
\hline Resingum (E445) & 2.000 & 4.000 & 5.000 & 6.000 & 7.000 \\
\hline Gum-arabic (E414) & 5.000 & 5.000 & 5.000 & 5.000 & 5.000 \\
\hline Citric acid (E330) & 0.500 & 0.500 & 0.500 & 0.500 & 0.500 \\
\hline Sodium benzoate (E211) & 0.250 & 0.250 & 0.250 & 0.250 & 0.250 \\
\hline Dye (E124) & 0.150 & 0.150 & 0.150 & 0.150 & 0.150 \\
\hline Dye (E110) & 1.400 & 1.400 & 1.400 & 1.400 & 1.400 \\
\hline Antioxidant (E320, E321) & 0.003 & 0.003 & 0.003 & 0.003 & 0.003 \\
\hline Water & 84.698 & 82.698 & 81.698 & 80.698 & 78.698 \\
\hline Total & 100.000 & 100.000 & 100.000 & 100.000 & 100.000 \\
\hline
\end{tabular}


Emulsions with constant amount of oil phase and different amount of gum-arabic

\begin{tabular}{|l|c|c|c|c|c|}
\hline \multirow{2}{*}{\multicolumn{1}{c|}{ Emulsion ingredients }} & \multicolumn{5}{c|}{ Ingredients content, wt \% } \\
\cline { 2 - 6 } & \multicolumn{5}{c|}{ Emulsion number } \\
\cline { 2 - 6 } & 6 & 7 & 8 & 9 & 10 \\
\hline Citrus oil & 6.000 & 6.000 & 6.000 & 6.000 & 6.000 \\
\hline Resingum (E445) & 4.000 & 4.000 & 4.000 & 4.000 & 4.000 \\
\hline Gum-arabic (E414) & 4.000 & 5.000 & 5.500 & 6.000 & 7.000 \\
\hline Citric acid (E330) & 0.500 & 0.500 & 0.500 & 0.500 & 0.500 \\
\hline Sodium benzoate (E211) & 0.250 & 0.250 & 0.250 & 0.250 & 0.250 \\
\hline Dye (E124) & 0.150 & 0.150 & 0.150 & 0.150 & 0.150 \\
\hline Dye (E110) & 1.400 & 1.400 & 1.400 & 1.400 & 1.400 \\
\hline Antioxidant (E320, E321) & 0.003 & 0.003 & 0.003 & 0.003 & 0.003 \\
\hline Water & 83.698 & 82.698 & 82.198 & 81.698 & 80.698 \\
\hline Total & 100.000 & 100.000 & 100.000 & 100.000 & 100.000 \\
\hline
\end{tabular}

Emulsions with different amount of oil phase and constant amount of starch

\begin{tabular}{|c|c|c|c|c|c|}
\hline \multirow{3}{*}{ Emulsion ingredients } & \multicolumn{5}{|c|}{ Ingredients content, wt $\%$} \\
\hline & \multicolumn{5}{|c|}{ Emulsion number } \\
\hline & 1 & 2 & 3 & 4 & 5 \\
\hline Citrus oil & 4.000 & 5.000 & 5.500 & 6.000 & 7.000 \\
\hline Resingum (E445) & 4.000 & 5.000 & 5.500 & 6.000 & 7.000 \\
\hline Starch (E1450) & 12.000 & 12.000 & 12.000 & 12.000 & 12.000 \\
\hline Citric acid (E330) & 0.500 & 0.500 & 0.500 & 0.500 & 0.500 \\
\hline Sodium benzoate (E211) & 0.250 & 0.250 & 0.250 & 0.250 & 0.250 \\
\hline Dye (E124) & 0.150 & 0.150 & 0.150 & 0.150 & 0.150 \\
\hline Dye (E110) & 1.400 & 1.400 & 1.400 & 1.400 & 1.400 \\
\hline Antioxidant (E320, E321) & 0.003 & 0.003 & 0.003 & 0.003 & 0.003 \\
\hline Water & 77.698 & 75.698 & 74.698 & 73.698 & 71.698 \\
\hline Total & 100.000 & 100.000 & 100.000 & 100.000 & 100.000 \\
\hline
\end{tabular}

Table 4

Emulsions with constant amount of oil phase and different amount of starch

\begin{tabular}{|l|c|c|c|c|c|}
\hline \multirow{2}{*}{\multicolumn{2}{c|}{ Emulsion ingredients }} & \multicolumn{5}{c|}{ Ingredients content, wt \% } \\
\cline { 2 - 6 } & \multicolumn{4}{|c|}{ Emulsion number } \\
\cline { 2 - 6 } & 6 & 7 & 8 & 9 & 10 \\
\hline Citrus oil & 5.500 & 5.500 & 5.500 & 5.500 & 5.500 \\
\hline Resingum (E445) & 5.500 & 5.500 & 5.500 & 5.500 & 5.500 \\
\hline Starch (E1450) & 8.000 & 10.000 & 11.000 & 12.000 & 14.000 \\
\hline Citric acid (E330) & 0.500 & 0.500 & 0.500 & 0.500 & 0.500 \\
\hline Sodium benzoate (E211) & 0.250 & 0.250 & 0.250 & 0.250 & 0.250 \\
\hline Dye (E124) & 0.150 & 0.150 & 0.150 & 0.150 & 0.150 \\
\hline Dye (E110) & 1.400 & 1.400 & 1.400 & 1.400 & 1.400 \\
\hline Antioxidant (E320, E321) & 0.003 & 0.003 & 0.003 & 0.003 & 0.003 \\
\hline Water & 78.698 & 76.698 & 75.698 & 74.698 & 72.698 \\
\hline Total & 100.000 & 100.000 & 100.000 & 100.000 & 100.000 \\
\hline
\end{tabular}


To acidify the emulsion to $\mathrm{pH}=3.3 \pm 0.7$ we used citric acid (E330) which enhances the preservative action and increases emulsion viscosity. The synthetic watersoluble dyes: Ponceau (E124) and Sunset Yellow (E110) were used to color the emulsions.

\subsection{Procedure of Emulsion Preparation}

Under the laboratory conditions the emulsions are prepared as follows:

- preparation of aqueous phase;

- preparation of oil phase;

- preparation of pre-emulsion;

- preparation of fine-dispersed emulsion (homogenization).

Preparation of aqueous phase. The main components are: water, sodium benzoate, stabilizer, citric acid, and other components according to the composition (Tables 1-4). All ingredients are introduced in the following sequence: prepared (purified) water; sodium benzoate; water-soluble dyes; stabilizer; citric acid. For better dissolution of the components we used $50 \%$ of necessary water. Gum-arabic is dissolved at $403 \mathrm{~K}$. Modified starch is dissolved at $298 \mathrm{~K}$.

The weighted sodium benzoate is loaded into the vessel with water under stirring and stirred for 5-7 min. Then the dyes are added and stirred for 10-12 min. Gumarabic is loaded at the speed of $100 \mathrm{rpm}$ and starch - at $40 \mathrm{rpm}$. The starch is introduced through the funnel because the air suction is inadmissible. After complete dissolution of gum-arabic or starch the citric acid is added and stirred for 5-7 min. Then the mixture remains to settle for $4-5 \mathrm{~h}$ till foam disappears $(4-5 \mathrm{~h}$ for gum-arabic and $10-12 \mathrm{~h}$ for starch).

Preparation of oil phase. The oil phase is prepared directly before pre-emulsion preparation in the vessel equipped with a stirrer. The sequence of components introduction: citrus oil; antioxidant; ester gum emulsifier.

The citrus oil is loaded into a vessel under stirring and heated to 298-403 K (298 K - for starch and $403 \mathrm{~K}-$ for gum-arabic). Antioxidant is dissolved in a small amount of oil, added to the mixture, then emulsifier is added. The stirring is continued to the complete dissolution (approximately 1-2 $\mathrm{h}$, the solution must be clear).

Preparation of pre-emulsion. The procedure takes place in a vessel equipped with a high-speed stirrer Silverson $(\sim 3000 \mathrm{rpm})$. The sequence of components introduction: aqueous phase; oil phase; residual amount of water.

The oil phase is loaded into the vessel with aqueous phase under stirring and stirred for $10 \mathrm{~min}$. The residual amount of water is added. The mixture temperature is $298-403 \mathrm{~K}$ and stirring is continued for additional $10 \mathrm{~min}$. The general stirring time is $20 \mathrm{~min}$.

Preparation of fine-dispersed emulsion (homogenization). Due to the sharp pressure difference on the head of two-staged high-pressure homogenizator the oil particles are crushed, uniformly distributed in the emulsion and stabilized by the stabilizer. The mixture temperature is $298-403 \mathrm{~K}$. To obtain the product with uniform density the stirrer in the vessels from which preemulsion is fed must work all the time.

Homogenization indexes:

- for the emulsion with gum-arabic the pressure is $28 / 4 \mathrm{MPa}$, number of cycles 2;

- for the emulsion with starch the pressure is $20 / 5 \mathrm{MPa}$, number of cycles 2 .

The emulsion is considered to be a stable one if the size of oil particles is less than 1 micron. If the product does not meet this demand, the repeated homogenization with other pressure is needed. After the homogenization and its repeated cycles (if necessary) the organoleptic and physico-chemical characteristics of the finished product are controlled.

\subsection{Analysis of the Obtained Emulsions}

For every emulsion we determined $\mathrm{pH}$, density, turbidity, viscosity, and average size of oil phase particles. To measure $\mathrm{pH}$ we used the laboratory $\mathrm{pH}$-meter (Anion 4100); density - usual densimeter of $\mathrm{AOH}-1, \mathrm{AOH}-2$, $\mathrm{AOH}-3, \mathrm{AOH}-4$, and $\mathrm{AOH}-5$ types; turbidity turbidimeter of $2100 \mathrm{P}$ type; viscosity - Brookfield viscosimeter. The average size of the particles was studied using EASTCOLIGHT 92012-ES (100x, 250x, 550x, $750 \mathrm{x})$ microscope and measured by $\mathrm{LS}^{\mathrm{TM}} 13320$ instrument using laser granulometric method.

The stability of the obtained emulsions was investigated by measuring particles diameter using laser granulometric method. The less the size of the particles, the more stable the emulsion. To control the emulsion stability the beverage is prepared and placed under direct light for $72 \mathrm{~h}$. If oil ring is formed during this time the emulsion is rehomogenized to obtain the particles of smaller size (till $1 \mu \mathrm{m})$. If the oil ring is absence the beverage is examined for shelf stability for 180 days.

The color stability is provided by using synthetic dyes which are more stable in comparison with natural ones under direct light for the entire period of shelf life. Beverage aroma and flavor (without taking into account the sugar-acid balance) are provided by using citrus oil. It is a fat-soluble aromatizer in the oil phase, therefore antioxidants (mixture of E320 and E321) are used to preserve the beverage aroma and flavor.

\section{Results and Discussion}

The characteristics of obtained emulsions are represented in Tables 5 and 6 .

Figs. 1-4 represent the distribution curves relative to the particles size for different emulsions. 
Characteristics of emulsions with gum-arabic

\begin{tabular}{|c|c|c|c|c|c|}
\hline Emulsion number & Viscosity, cP & $\begin{array}{c}\text { Dissolution turbidity } \\
0.025 \%, \text { NTU }\end{array}$ & Particles size $D, \mu \mathrm{m}$ & Density, $\mathrm{g} / \mathrm{cm}^{3}$ & $\mathrm{pH}$ \\
\hline 1 & 14.00 & 168.00 & 0.51 & 1.03 & 2.70 \\
\hline 2 & 15.00 & 180.00 & 0.66 & 1.06 & 3.20 \\
\hline 3 & 16.00 & 192.00 & 0.71 & 1.09 & 3.30 \\
\hline 4 & 17.00 & 216.00 & 0.90 & 1.10 & 3.90 \\
\hline 5 & 18.00 & 240.00 & 1.10 & 1.04 & 2.60 \\
\hline 6 & 14.00 & 192.00 & 0.75 & 1.06 & 3.07 \\
\hline 7 & $\mathbf{1 5 . 0 0}$ & $\mathbf{1 8 0 . 0 0}$ & $\mathbf{0 . 6 6}$ & 3.20 \\
\hline 8 & 15.50 & 174.00 & 0.60 & 1.09 & 3.30 \\
\hline 9 & 16.00 & 168.00 & 0.56 & 0 & 3.40 \\
\hline 10 & 17.00 & 154.00 & 0.50 & & 3.80 \\
\hline
\end{tabular}

Table 6

\section{Characteristics of emulsions with starch}

\begin{tabular}{|c|c|c|c|c|c|}
\hline Emulsion number & Viscosity, cP & $\begin{array}{c}\text { Dissolution turbidity } \\
0.025 \%, \text { NTU }\end{array}$ & Particles size $D, \mu \mathrm{m}$ & Density, $\mathrm{g} / \mathrm{cm}^{3}$ & $\mathrm{pH}$ \\
\hline 1 & 20.00 & 143.00 & 0.67 & 1.03 & 2.60 \\
\hline 2 & 22.00 & 156.00 & 0.73 & 1.05 & 3.00 \\
\hline 3 & 23.00 & 170.00 & 0.75 & 1.09 & 3.30 \\
\hline 4 & 24.00 & 182.00 & 0.84 & 1.10 & 4.07 \\
\hline 5 & 26.00 & 196.00 & 0.97 & 1.04 & 2.70 \\
\hline 6 & 19.00 & 210.00 & 0.98 & 1.06 & 3.10 \\
\hline 7 & 21.00 & 196.00 & 0.91 & 1.07 & 3.20 \\
\hline 8 & 22.00 & 184.00 & 0.83 & $\mathbf{1 . 0 7}$ & $\mathbf{3 . 3 0}$ \\
\hline $\mathbf{9}$ & $\mathbf{2 3 . 0 0}$ & $\mathbf{1 7 0 . 0 0}$ & $\mathbf{0 . 7 5}$ & 1.10 & 3.80 \\
\hline 10 & 25.00 & 157.00 & 0.68 & & \\
\hline
\end{tabular}

Fig. 1. Distribution curves relative to the particles sizes for the emulsions with constant amount of gum-arabic ( $5 \mathrm{wt} \%$ ) and different content of oil phase, wt \%: $8.0(1) ; 10.0(2) ; 11.0(3)$; 12.0 (4)

and 14.0 (5). Number of the curve corresponds to the number of emulsion in Table 1

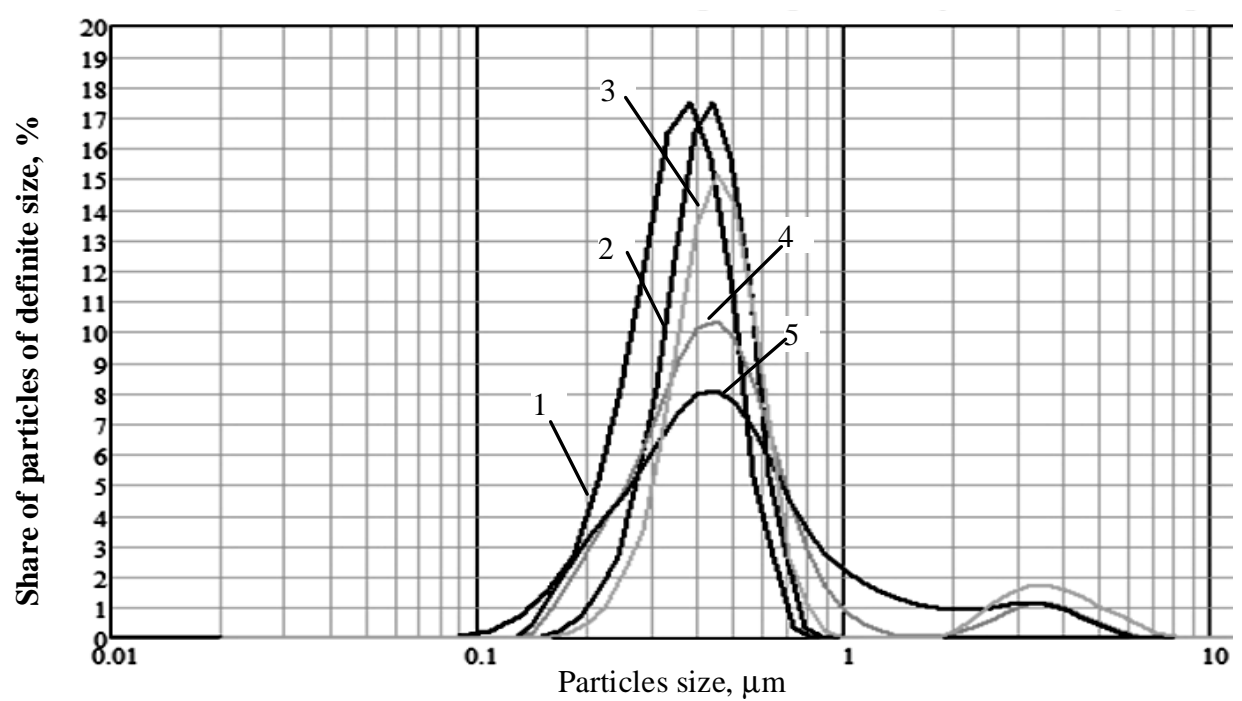



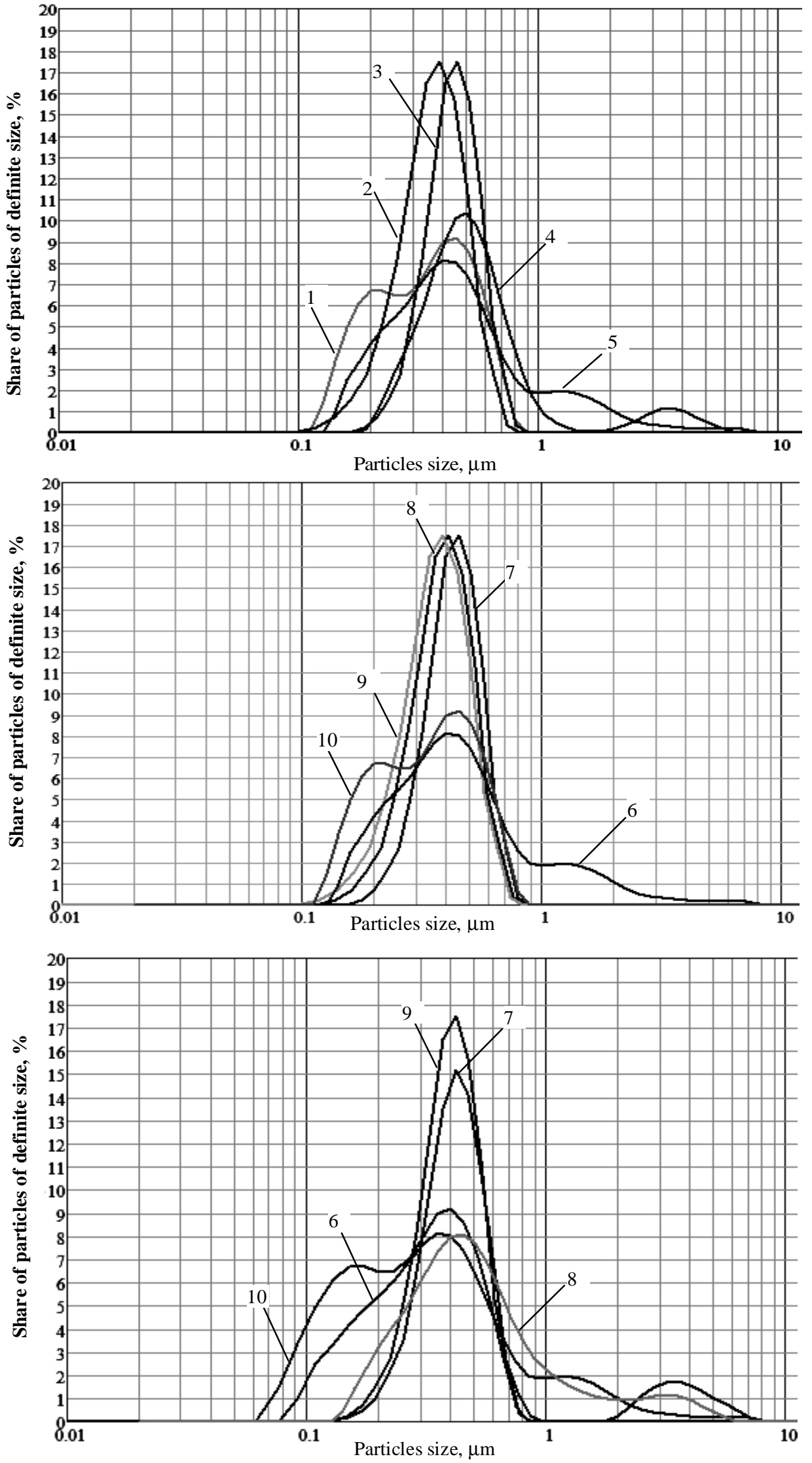

Fig. 2. Distribution curves relative to the particles sizes for the emulsions with constant amount of starch (12 wt \%) and different content of oil phase, wt \%: 8.0 (1); 10.0 (2); 11.0 (3); 12.0 (4) and 14.0 (5). Number of the curve corresponds to the number of emulsion in Table 3

Fig. 3. Distribution curves relative to the particles sizes for the emulsions with constant amount of oil phase (10 wt \%) and different content of gum-arabic, wt \%: 4.0 (6); 5.0 (7); 5.5 (8); 6.0 (9) and 7.0 (10). Number of the curve corresponds to the number of emulsion in Table 2

Fig. 4. Distribution curves relative to the particles sizes for the emulsions with constant amount of oil phase (11 wt \%) and different content of starch, wt \%: 8.0 (6); $10.0(7) ; 11.0(8) ; 12.0(9)$ and 14.0 (10). Number of the curve corresponds to the number of emulsion in Table 4 
For the emulsions with gum-arabic with the increase in oil phase content from 8 to $14 \mathrm{wt} \%$ the average size of the particles increases from 0.51 to $1.1 \mu \mathrm{m}$; viscosity - from 14 to $18 \mathrm{cP}$; turbidity - from 168 to 240 NTU and density from 1.03 to $1.1 \mathrm{~g} / \mathrm{cm}^{3}$ (Table 5, Fig. 1). Concerning the emulsions with starch the same increase in oil phase content increases the average size of the particles from 0.67 to $0.97 \mu \mathrm{m}$, viscosity - from 20 to $26 \mathrm{cP}$; turbidity - from 143 to $196 \mathrm{NTU}$ and density - from 1.03 to $1.1 \mathrm{~g} / \mathrm{cm}^{3}$ (Table 6 , Fig. 2). However, the particles size must be limited by $1 \mu \mathrm{m}$, because even small amount of the particles with greater size results in the formation of unstable emulsion during storage. Therefore, on the basis of obtained results the emulsions No. 2 with gum-arabic (Fig. 1, curve 2) and No.3 with starch (Fig. 2, curve 3) were found to be the best ones. The optimum amount of oil phase in these emulsions is 10 and $11 \mathrm{wt} \%$, respectively.

While increasing the amount of oil phase in the system with the constant amount of stabilizer the moment occurs when the stabilizer quantity is insufficient to stabilize the emulsion. Hence, it is important to determine the stabilizer optimum amount at the optimum amount of oil phase. For this purpose five samples were investigated (Figs. 3 and 4) and their main characteristics are represented in Tables 5 and 6 .

With the increase in gum-arabic content from 4 to $7 \mathrm{wt} \%$ (oil phase content is $10 \mathrm{wt} \%$ ) the average size of the particles decreases from 0.75 to $0.5 \mu \mathrm{m}$ and turbidity from 192 to 154 NTU. At the same time its viscosity increases from 14 to $17 \mathrm{cP}$ and density - from 1.04 to $1.1 \mathrm{~g} / \mathrm{cm}^{3}$ (Table 5, Fig. 3). The increase of starch content in the emulsion from 8 to $14 \mathrm{wt} \%$ (oil phase content is $11 \mathrm{wt} \%$ ) decreases the average size from 0.98 to $0.68 \mu \mathrm{m}$ and turbidity - from 210 to 157 NTU. We observed the increase in viscosity from 19 to $25 \mathrm{cP}$ and density - from 1.04 to $1.1 \mathrm{~g} / \mathrm{cm}^{3}$ (Table 6 , Fig. 4).
Fig. 5. Distribution of particles according to the size in the emulsion No.7 with gum-arabic at different pressures $(\mathrm{MPa})$ : 24/4 (1); 26/4 (2); 28/4 (3) and $30 / 4(4)$

Fig. 6. Distribution of particles according to the size in the emulsion No.9 with starch at different pressures $(\mathrm{MPa})$ : $16 / 5(1) ; 18 / 5(2) ; 20 / 5(3)$ and $22 / 5(4)$
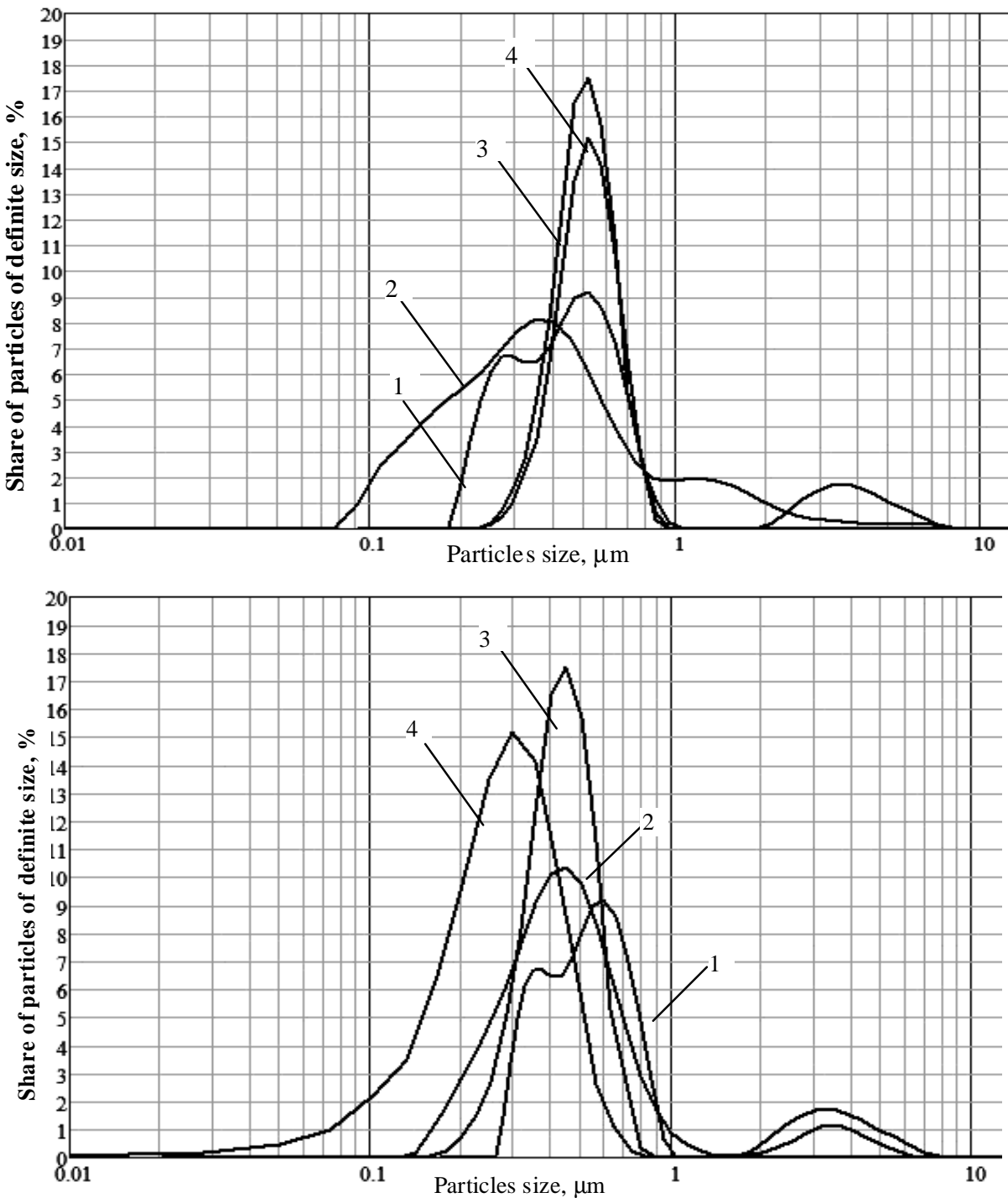
So, the increase in stabilizer content at the constant amount of oil phase increases the emulsion stability due to the decrease in particles size and slightly affects the turbidity and viscosity. Moreover, it increases the emulsion cost price. Therefore, taking into account the level of product stability and turbidity, as well as future price of the obtained emulsions, the optimum contents of aqueous stabilizer and oil phase for the emulsion with gum-arabic (Table 5, Fig. 3, curve 7) are 5 and $10 \mathrm{wt} \%$, respectively, and for the emulsion with starch (Table 6, Fig. 4, curve 9) these values are 12 and $11 \mathrm{wt} \%$, respectively.

To determine the optimum homogenization pressure we used the emulsions with the best characteristics. Four similar samples of the emulsion with gum-arabic (Table 2, No.7) and with starch (Table 4, No.9) were prepared according to the procedure and homogenized under different pressures. We varied the upper pressure, which affects the particles size and the bottom pressure, providing the emulsion stability, was constant. Step-interval for upper pressure is $2 \mathrm{MPa}$. The results are represented in Figs. 5 and 6.

Thus, the optimum parameters of homogenization process for the emulsion with gum-arabic are: pressure first step/second step - 28/4 MPa, number of cycles -2 , particles size - less than $1 \mu \mathrm{m}$ (Fig. 5, curve 3). For the emulsion with starch: pressure - first step/second step $20 / 5 \mathrm{MPa}$, number of cycles -2 , particles size - less than $1 \mu \mathrm{m}$ (Fig. 6, curve 3).

It should be noted that during storage of the beverages on the basis of prepared emulsions we observed no oil ring on the beverage surface, as well as no changes in flavor, color and aroma. If we compare two investigated stabilizers (starch E1450 and gum-arabic E414) we observe the following differences. The starch has higher emulsifying ability compared with gum-arabic [10]. It means that higher homogenization pressure, and hence, higher energy consumption is needed. The cost price of the emulsions with starch is lower and more stable than that of the emulsions with gum-arabic. Moreover the sources of gum-arabic supply are questionable. The main advantages of gum-arabic compared with starch are the following: it is easy-to-use (during dissolution) and the emulsion system with it has higher turbidity and stability while storage.

\section{Conclusions}

We confirmed the advisability of using hydrocolloids for emulsification and homogenization of oilwater emulsions and optimum parameters of emulsifier usage were determined.

The optimum amount of water-soluble emulsifier and oil phase was determined to be 12 and $11 \mathrm{wt} \%$, respectively, for the emulsions with starch; for the emulsions with gum-arabic these values are 5 and $10 \mathrm{wt} \%$, respectively.

We determined the technological parameters for the homogenization of the emulsions with starch: pressure first step/second step - 20/5 MPa; number of cycles -2 ; size of the prepared emulsion particles - less than $1 \mu \mathrm{m}$ under the conditions of starch introduction into the aqueous phase at $298 \mathrm{~K}$, oil phase temperature $298 \mathrm{~K}$ and mechanical stirring by anchor stirrer with $40 \mathrm{rpm}$. The conditions for pre-emulsion preparation: room temperature of starch and oil phase, stirring by Silverson stirrer with $3000 \mathrm{rpm}$ for $20 \mathrm{~min}$.

The technological parameters for the homogenization of the emulsions with gum-arabic: pressure first step/second step - 28/4 MPa; number of cycles -2 ; size of the prepared emulsion particles - less than $1 \mu \mathrm{m}$ under the conditions of gum-arabic introduction into the aqueous phase at $303 \mathrm{~K}$, oil phase temperature $303 \mathrm{~K}$ and mechanical stirring by anchor stirrer with $100 \mathrm{rpm}$. The conditions for pre-emulsion preparation: room temperature of gum-arabic and oil phase, stirring by Silverson stirrer with $3000 \mathrm{rpm}$ for $20 \mathrm{~min}$.

During storage of beverages based on the obtained emulsions no oil ring or "creaming" was observed indicating the system stability. The obtained results are important and useful to develop new foodstuffs.

\section{References}

[1] Borisenko O., Alekseev Yu. And Klimova S.: Harchovi Ingredienty: Syrovyna i Dobavky, 2002, 2, 18.

[2] Phillips G. and Williams P. (Eds.): Handbook of Hydrocolloids. Woodhead Publ., Cambridge 2000.

[3] McKenna B. (Ed.): Texture in Food. Woodhead Publ., Cambridge 2003.

[4] Bogach A.: Produkty Harchuvannya i Napoi, 2003, 4, 10.

[5] Stephen P.: US Pat. 6576285, Publ. June 10, 2003.

[6] Imeson A. (Ed.): Thickening and Gelling Agents for Food, $2^{\text {nd }}$ edn. Blackie Academic and Professional, London 1999.

[7] Whistler R., Miller J. and Paschall E. (Eds.): Starch Chemistry and Technology, $2^{\text {nd }}$ edn. Academic Press, FL 1984.

[8] Atwell W. and Thomas D.: Starches. Am.Ass.Cereal Chem., St.Paul, MN 1997.

[9] http://www.applegate.co.uk/

[10] Aimeson A.: Pishchevye Zagustiteli, Stabilizatory, Geleobrazovateli. Professiya, Sankt-Peterburg 2012.

\section{ВПЛИВ ГІДРОКОЛОЇДІВ НА ЯКІСТЬ ЕМУЛЬСІЇ ТИПУ ОЛІЯ-ВОДА ДЛЯ ХАРЧОВИХ ПРОДУКТІВ ТА НАПОЇВ}

Анотація. Удосконалено спосіб приготування емульсій з гідроколоїдами, які є стабілізаторами-емульгаторами, - гуміарабіком та крохмалем - внаслідок введення нових технологічних показників (співвідношення оливної та водної фази, послідовність та параметри введення інгредієнтів у відповідні фази, параметри приготування пре-емульсії та процесу гомогенізаиії). Досліджено зразки харчових емульсій з використанням різноі кількості гуміарабіку або крохмалю як стабілізатора (при сталій кількості оливної фази) та зразки емульсій зі змінною кількістю оливної фази і постійною кількістю стабілізатора. Встановлено, шо оптимальне співвідношення водного стабілізатора та оливної фази емульсії характеризується отриманням максимальної кількості частинок емульсії розміром до 1 мікрона.

Ключові слова: ароматичні емульсї, гідроколоїд, стабілізатор, крохмаль, гуміарабік. 